\title{
Amendment of the Transfusion Act: Easing of Legal Provisions on Salvaged Blood Preparations
}

Washed wound blood used in automated autotransfusion (AAT) is taking on an ever greater importance in autologous blood donation practice. AAT involves, inter alia, that, after washing, the red cells are collected in a bag or other recipient and labelled. This constitutes the manufacture of products that are blood products as defined in section 2 no. 3 of the Transfusion Act (Transfusionsgesetz - TFG) [1, 2]. However, the Federal Constitutional Court ruled that (so-called Frischzellen-Urteil (live cell ruling) of February 16, 2000 BVerFGE 102,26), as long as the production of such salvaged blood preparations and their operating room use are performed by one and the same person or under his or her instruction, as would usually be the case, the Federal Drug Law (Arzneimittelgesetz - AMG) [3] does not apply (cf. also section 4a sentence 1 No. 3 AMG).

The situation changes, however, from both the factual and legal perspectives in the case of wound blood preparations that must be irradiated and, for this purpose, need to be transferred from the operating room to another hospital ward or outside facility so that the producing/using physician temporarily forfeits the power of disposition over the drug. Under the law governing drugs, this act of supply amounts to marketing as specified in section 4 subs. 17 of the AMG. Consequently, the provisions of the AMG apply, especially those governing the manufacturing authorization pursuant to section 13 AMG and the provisions on the ordinance on radiopharmaceuticals and drugs treated with ionizing radiation of 1987 (Verordnung über radioaktive oder mit ionisierenden Strahlen behandelte Arzneimittel - AMRadV) [4].

The AMRadV also stipulates exemptions from the basic marketing ban on radioactive drugs or drugs treated with ionizing radiation as specified in section 7 subs. 1 AMG for bloodbased drugs. According to section 1 subs. 2 AMRadV, bloodbased drugs produced using electron, gamma or X-rays to inactivate blood components may be placed on the market, i.e. supplied to third parties, if certain prerequisites are met. One of these is for the irradiated blood-based drug to have undergone a marketing authorization procedure. This is logical in the case of similar blood-based drugs which are irradiated according to a standardized procedure because irradiation basically produces a different drug that is tested as part of the marketing authorization procedure and can then be reproduced according to the authorized specimen.

However, irradiated wound blood preparations are blood drugs that are produced on a customized basis and, due to the production process and their characteristic features, elude standardized reproducibility. A model marketing authorization, which is an option for other irradiated blood products, such as preoperative autologous blood donations, does not seem feasible for irradiated salvaged blood preparations. This is the technical reason why the Amendment of the TFG, by amending section 1 subs. 2 and 3 of the AMRadV exempts irradiated wound blood preparations from the obligation to obtain a marketing authorization. Thanks to this exemption, these drugs are marketable even without a regulatory marketing authorization.

The basic requirement for such products to be covered by a manufacturing authorization is further eased by providing for the so-called 'minor' manufacturing authorization. The amendment of section 14 subs. 2 AMG now permits the combination of the functions of production and control manager in one person, not only for autologous blood donations but also for irradiated salvaged blood. This, too, is subject to the prerequisite that the production (specifically irradiation), testing, and use are done within the sphere of responsibility of a hospital department or other medical facility. Hence, the essential criterion is that the producing and testing department or facility has responsibility for and influence on the use of the irradiated salvaged blood. This can be achieved, for instance, if the producing and testing facility designates a correspondingly qualified person to use the irradiated blood product in the operating room or at the ward, or if the producing

\begin{tabular}{ll}
\hline KARGER & @ 2004 S. Karger GmbH, Freiburg \\
Fax +49 7614520714 & Accessible online at: \\
$\begin{array}{l}\text { E-mail Information@Karger.de } \\
\text { www.karger.com }\end{array}$ & www.karger.com/tmh
\end{tabular}

\section{KARGER}

www.karger.com
Ministerialrat Friedger von Aue

Bundesministerium für Gesundheit und Soziale Sicherung

Am Propsthof 78a, D-53121 Bonn

Tel. +49 228 941-11 50, Fax -49 27

E-mail friedger.vonauer@bmgs.bund.de 
and testing facility issues instructions, for which the facility assumes responsibility, to the department using the blood. If the product is used in conformity with these instructions by the surgeon or anesthetist, use will be deemed to take place within the sphere of responsibility of the producing and testing department, which implies that the latter is liable both for the accuracy of the instructions and the use of the product according to these instructions.

F. von Auer, Bonn

\section{References}

1 Transfusionsgesetz (Transfusion Act), July 1, 1998, Bundesgesetzblatt I, p 1752, at last amended by article 20 of the ordinance of November 25, 2003 Bundesgesetzblatt I, p 2304

2 von Auer F: Autologous transfusion - pros and cons from the health policy perspective. Infus Ther Transfus Med 2002;29:110-116.

3 Arzneimittelgesetz (Drug Law), December 11, 1998, Bundesgesetzblatt I, p 3585, ammended by law of August 21, 2002, Bundesgesetzblatt I, p 3352.

4 Ordinance of November 28, 1987, Bundesgesetzblatt I, p 502, at last amended by article 10 of the ordinance of July 20, 2001 Bundesgesetzblatt I, p 1714. 